\title{
ВРЕМЕ У РОМАНУ ТЕСТАМЕНТ ВИДОСАВА СТЕВАНОВИЋА И ПОЕЗИЈИ АУГУСТИНА „ТИНА” УЈЕВИЋА ${ }^{* *}$
}

\begin{abstract}
У раду је дата компаративна анализа појма времена у Стевановићевом и Ујевићевом стваралаштву, кроз постструктуралистички приказ опозиције субјекта и времена. Обојица аутора увиђају цикличну природу времена и онтолошку супериорност судбине у односу на субјектове пројекције. Међутим, док Стевановић кроз приказ села Као тумачи време као институционализовано и зато иманентно отуђено од субјекта, Ујевић указује на могућност деридијанског зближавања субјекта и времена које је у својој потенцијалности семантички паралелно човечанству и, утолико, самом субјекту. „Вечно враћање” времена у Стевановићевом роману служи ради истицања метафизичке прошлости која је, мада бесмислена, арбитрарно прихваћена; Ујевић понављањем утврђује садашњост као феноменолошко средиште времена, сферу измирења не само временских тачака у субјектовом искуству већ и субјекта и тоталитета историје.

Кључне речи: Видосав Стевановић, Тин Ујевић, Жак Дерида, време, субјект, догађај, институција.
\end{abstract}

\section{I. Увод; метафизички континуитет времена код Стевановића и Ујевића}

У роману Тестамент Видосава Стевановића и у поезији Аугустина „Тина” Ујевића, време измиче могућности означавања утолико што упућује на увек нове означиве просторе, дефинисане у екстази напуштања семантике временских сегмената. Утолико је искуство времена пандан визији „задовољства у тексту" код Ролана Барта, до ког долази укидањем институционализованог искуства у корист апстрактног, дисперзованог искуства које реализује једнако близак контакт са свим културним и дискурзивним модусима

\footnotetext{
*djurannikola@yahoo.com

** Овај рад је написан у оквиру пројекта Друштвене кризе и савремена српска књижевност и култура: начионални, регионални, европски и глобални оквир (број 178018), који финансира Министарство за науку и технолошки развој Републике Србије.
} 
(в. Барт 1975: 38). Премда је неодредиво, време је за Стевановића и Ујевића, ипак и једино извесно: оно трага за људима-објектима, који су привремени сасуд његове бартовски ,драге” фамилијарности, и њихову очајну визију хаоса реконструише у визију варијабилног, трансисторијског смисла. Очај код протагониста двојице аутора јесте спознаја да времена нема, док је њихова катарза свест да време, налик језику, настаје „негде тамо” (Барт 1975: 8), док протагониста, ослобођен граница̄ актуелности, жуди за њим. У циклусу укидања и реконструкције самог себе, време аболира слику примарности код протагониста, као да упућује не на алтернативну, већ оригиналну примарност „негде тамо”.

Постојање у садашњости за Стевановића и Ујевића јесте онтолошко искушење ком се заборавља време у својству семантички неутралног, метафизичког објекта док субјект, с друге стране, увиђа време као културну институцију, зависну било од утицаја друштва (Стевановић) или појединца (Ујевић). Како субјект обојице аутора располаже надмоћном стихијом времена које га може или присајединити колективу или лишити колективних одредница̄ и поништити, дијалог субјекта и времена каналисан је субјектовим страхом од одсуства судбинских детерминанти (в. Требежник 2019): уходане обрасце надомешћује субјектова воља која, по установљењу, постаје засебна институција.

\section{II. Институционална транссубјективност времена у роману Тестамент Видосава Стевановића}

У Стевановићевом роману Тестамент, примордијални простор настајања времена јесте фиктивно село „Као”. За Стевановића, време је „ouroboros”, оно „не протиче”, већ „кружи и у кружењу свом - једе се изнутра као змија" (Стевановић 2008: 122). Време, универзалистички везано строго за простор села Као - чиме се имплицира да су појмови времена изван Кала строго емпиријски, привидни - намеће се противно опирању Стевановићевих бројних протагониста, који чезну да се отргну примордијалности каљанских обичаја. Када у XVI поглављу протагониста артикулише своје чуђење звуковима у ноћи, нарочито топотом коња, он наводи да су коњи, зато што галопирају недефинисаном, мистичном путањом, и сами можда бића изван физичког света. Немогуће је, тврди посетилац Кала, тврдити да страна створења пролазе „кроз Као”, јер њима, мада типичним за то село, „није могуће одредити путању”. Галопирајући преко Кала, ти коњи су одавали утисак као да час „одјекују са земље”, час се „дижу у небеса”, час „хуче међу звездама”, час „допиру са месеца” (Стевановић 2008: 80). Посетиочеву неверицу крунише његова свест о томе да сами становници Кала спавају и не чују космички снажну буку коњског галопа. На крају, у својој катарзи он увиђа: сабласни јахачи коња-утвара̄ били су „наши мртви који су се вратили, који су ме позивали к себи” (Стевановић 2008: 81). За становнике Кала, 
есхатолошки сусрет живота и смрти, а тиме и сусрет сва три аспекта времена (прошлости, садашњости и будућности) јесте институционализовани чинилац свакодневице; странце који на овај стални тоталитет времена гледају са чуђењем Каљани жигошу и осуђују, или их у срећнијем случају игноришу. Описујући звуке галопа, Стевановић се служи перфектом, уз местимични аорист: долазак мртвих се већ десио, али он се у својој аисторичности протеже и на будућност - мртви детерминишу протагонистину судбину, зовући га к себи.

Као средство онтолошки неизоставно за дискурс датог друштва, време уткива у живот Каљана културолошку слику поретка и сигурности. У IV поглављу, аутор говори о времешном матријарху једног каљанског домаћинства, „прамајци Цвети”, чија је истовремено злослутна и божанска појава покретач свих дешавања у домаћинству. И кад је одсутна, прамајка доминира подсвешћу укућана, предодређује њихове планове и радње, подрива њихове бунтове. Куда год да неко од укућана крене, „непрестано се враћа одакле је пошао, на праг своје куће и пред прамајкине сасушене ноге" (Стевановић 2008: 23). Са̂м прамајчин помен нечијег имена чини да гости, или укућани који су напустили домаћинство, дођу код ње у кућу; она артикулише и судбине нерођене деце, предвиђа и утврђује њихов идентитет и будућност. За случај да појединац, презасићен туробним ритуализмом, пожели да напусти домаћинство, неименовани мушки посматрач, ког Стевановић именује само као „онај неко”, опомиње њега и цео колектив: „Да видимо докле ћете? Да видимо шта ћете сутра кад ње више не буде" (Исто: 23)? У целом IV поглављу, једино у опоменама посматрача присутан је футур: у остатку текста доминира неизбежна делатност перфекта.

Својом дуговечношћу симболизујући извесност и силу времена, прамајка управља поларним елементима постојања, чиме неретко институционализује апсурдне, само у строго ритуалистичком дискурсу каљанског домаћинства схватљиве чинове. На пример, ватра коју прамајка ложи и разгрева има функцију да зими греје укућане, а лети их хлади; одагнава осећај смрзавања, иако је и са њом хладно; жеже дланове и образе; смуди косе; кува храну. Најзад, у свести занесеног посматрача, прамајкина ватра може, налик визији путника из XVI поглавља Тестамента, да синтетише монструозне приказе митолошких и религиозних конотација̄. Прамајка делује из прошлости, онемогућујући бекство у будућност, на шта Стевановић упућује употребом перфекта за сваки од глагола. Изненадна смрт прамајке пропраћена је песимизмом укућана, нарочито мушкараца - симбола зависног и трајно недозрелог патријархата. Опомињући мушки коментатор, „онај неко”, понавља своју неверицу у постојање будућности без сакралног, матријархатског времена: „И ми бисмо отишли да знамо куда. Богами бисмо отишли” (Исто: 26)!

Стевановић, у суморно конзервативном контексту каљанске традиције, указује да воља колективизираног субјекта представља датост; са̂м народ сублимира своје одлуке у метафизички образац времена. Док о свом поимању саме природе времена Стевановић пише служећи се презентом, о својим бизарним искуствима у селу Као приповеда у перфекту и аористу. Садашњост 
постоји у свести субјекта, посетиоца Кала, док се одвијање времена, али и одређивање будућности, одвија у колективно-митској прошлости, која се, речима Валтера Бењамина, открива свим будућим генерацијама кроз максиме искупљења (в. Бењамин 2007: 254): садашњост и будућност постоје како би се прошлости дао историјски смисао. У XXX поглављу Тестамента, судбинско наслеђе је у алегоријској вези са старозаветним митом о изгону из едемског врта (в. Стевановић 2008: 152-153); Стевановић, пак, наводи да се социјални и културни усуд друштва не заснива на греху, већ пре на низу дијалога сваког од чланова друштва са „врховним” (Исто: 152). Смисао сваког преговора са коначним принципом јесте покушај дешифровања времена, а отуд и кодекса који, упоредо са несталним, хировитим временом, радикално осцилује: у несталној, сваки час другачијој семантичкој перспективи каљанског друштва, дешава се да нпр. вредноћа буде кажњена а лењост награђена, или да дрски и револуционарни појединци буду хваљени а послушни - опомињани (в. Исто: 153). Време - Стевановићев протагониста закључује - јесте културно утврђена афирмација тог семантичког нереда. Пошто у трибалистичком контексту Каљана време јесте ритуално понављање, субјект који холистички поима време схвата га као вечност, а свој боравак у Калу као „бесмртност”. „(Б)есмртност је у суштини једноставна ствар и значи непрекидно понављање истог; мени се допада зато што не морам да се трудим и да мислим. Како ми је данас, тако ће ми бити заувек; ствари се понављају, догађаји круже, једно замењује друго које је опет исто као прво, нема новости, изненађења и сличних глупости" (Исто: 154).

Каљани не покушавају да измене бесмисао света: уместо тога, они, сходно увиду Филипа Кејна, потискују бесмисао трагичном, али охрабрујућом илузијом смисла, тим утврђенијом што више прети „ван-институционални” бесмисао. „Свест о страхоти постојања потире деловање - за које су потребни дистанца и илузија. (...) Можемо поднети патњу. Али не можемо поднети бесмислену патњу, патњу без икаквог разлога. Зато патњи дајемо смисао. Стварамо смисао. Стварамо илузију" (Кејн 2007). У свом ничеанском осврту на време у Тестаменту, Стевановић Каљанима приписује снажну веру у бесмислену, но ипак бесмртну прошлост. Мада бесмисао од свих времена једино не поништава прошлост, она је именује као „потребну дистанцу и илузију", које су, бар за саме Каљане, једине извесне насупрот небићу садашњег и будућег времена.

\section{III. Феноменолошка непосредност времена у поезији Тина Ујевића}

Код Ујевића, време се открива као садашњост која у себи сабира цео ток историје: цело субјектово искуство већ се одвило у искуствима његових безбројних претходника и тек ће се одвијати у генерацијама које следе за њим. Зато је песимизам којим Ујевићев субјект започиње песму убрзо поништен ауторовим уверавањем да судбинска патња не припада само њему, 
појединачном субјекту већ човечанству. Као врховни егзистенцијални ментор, време у Ујевићевој песми Побратимство лица у свемиру указивањем на своју свеприсутност релативизује солипсистичко поимање живота, оличено у осећањима страха и охолости. Да би разумео време, субјект мора да остави за собом свој его, због чега га аутор песме саветује: „Не бој се!” и потом „Не горди се!” (Ујевић 2003: 144).

Индивидуа је реплика човечанства, чију судбину дели, али њен универзални контакт са временом уткива у њу и свест о сопству. Та свест је „себични печат један насред чела” (Ујевић 2003: 144), компромисна граница између особе и колектива која одржава осећај нужности значења код особе. Пуко понављање твари у космосу доводи „до уласка у одсуство, у нулти степен значења" (Барт 1975: 41); како би субјект остао распознатљив у свемиру упркос истодобности са тоталитетом, његов особени чин понављања мора да представља не утврђивање старих егзистенцијалних истина̄, но њихово укидање, иконокластију (в. Барт 1975: 43). Потом, иконокластија утире пут новој, субјектовој истини - Бартово „блаженство”, или Ујевићева „очајничка срећа”, спознати су када субјект „деполитизује оно што је очигледно политичко, и политизује оно што то очигледно није” (Барт 1975: 44). Ујевићев субјект достиже блаженство управо када досегне исту космичку измештеност која важи и за само време, које, попут језика, битише „негде тамо”. У Побратимству, Ујевић своју „очајничку срећу” утврђује путем свог присуства у свим аспектима постојања, али, више од тога, у својој свести о томе да саме његове бити нема. „Ја сам у неком тамо незнанцу, и на звијезди / далекој распреден, а овдје у једној нити, у свијету угаслом, разбит у свијету што језди, / па кад ћу ипак бити тамо у мојој бити"? Именилац субјектовог небића јесте „себични печат”, институционална подлога која постоји да би била укинута/деполитизована, јер без ње нема потраге за значењем, а тиме ни за временом које је, како Ујевић назначује, увек садашње, тј. увек „ново” (в. Барт 1975: 40-42).

Садашњост је за Ујевића сакрално време јер се вечито самообнавља: прошлост се реконструише а будућност се ближи и разоткрива у пророчкој метонимичности трајућег тренутка. Аналогно Ујевићевој песничкој сакрализацији, мислилац Жак Дерида садашњост сматра метафизичким временом, које, мада онтолошки извесније од прошлости и будућности, никад није до краја дато субјекту - увек измиче пред превеликом физичношћу прошлости. Уместо „датости”, садашњост је, Дерида тврди, увек у стању одлагања („différance”), дефинисаном у измицању непосредног тренутка субјектовом разумевању које је у својој перцепцији догађаја нужно корак иза саме непосредности. Зато ће се за Ујевића садашњост увек тек догодити; штавише, она ће се поновити и кристалисати безброј пута, пошто емпиријску садржајност садашњег тренутка субјект никада у целости не може да исцрпи. У песми Вјечни прстен, Ујевић хегелијански призива садашњост у њеној атемпоралној суштини: не садашњост која траје и умире у свести субјекта, већ онтолошки укотвљену у јединственом значењу, сходно ком је могуће стећи суштинску визију историје и самог себе. Та одлагана метафизичка са- 
дашњост, на коју треба чекати „хиљаду хиљада / и хиљаду љета”, не само да својој неухватљивости дугује само своје постојање већ, баш зато што она јесте „негде тамо”, открива субјекту моћ истинске, прочишћене перцепције - „новог освјетљења”. У садашњости, никаква емпиријска препрека не може да заустави субјектову трансценденцију. „Само ипак неће тада, надајмо се, / да нас јоште тару ове бриге ружне, / и да полет у вис догађаји косе, / и пламен за женом наше усне кужне”. Одбацивање страха и гордости у Побратимcтву, отуд, јесте катарктичка припрема за садашњост која је једино истинито време, лишено историчких фарси ега. Но, Ујевић - опет, у духу Дериде, тј. његовог учења о улози вере у субјектовом размишљању и доношењу одлука̄ - компромисно задржава позицију субјекта са „себичним печатом”: он зна да не може разумети са̂м садржај садашњости „негде тамо”, и остаје му нада да ће га она прочистити од „брига̄ ружних”, да се она, ако постоји, збиља разликује од профане садашњости којом је засићен.

Ујевић је у два аспекта свог поимања времена паралелан Стевановићу: разумевању ничеанског „вечног враћања” и аналогији између садашњости и будућности на темељу њихове неухватљиве природе. Ипак, уместо колективно детерминисаног времена које у Калу има функцију судбине, Ујевићева аисторична садашњост припада појединцу и његовој одлуци. Одложени статус садашњости није егзистенцијална препрека субјекту, већ темељ његове наде: ако је садашњост емпиријски неодредива, то је зато што се она бесконачно искупљује у свом кружењу. Садашњост се није десила јер се чека, али и јер се у чекању понавља, на шта Ујевић одговара „љубављу према понављању” коју наводи Ниче у Ессе Ното. У Свакидашњој јадиковци, Ујевић у презенту описује трагизам свог постојања али и услове у којима његова патња има смисао: зато што може осетити пуноћу свог бола, он призива Божја „обећања блистава” (Ујевић 2003: 5), и чезне да изнађе из себе Божју „ријеч” (Исто: 7), која је „жељна да завапи” (Исто: 7). Ујевићев субјект је кјеркегоровски ослоњен на критичну неприкосновеност садашњег тренутка: уместо вере у будућност, дата је једино садашњост у својој синтези страшног и узвишеног. Ујевићева трагедијом означена садашњост накнадно упућује на деридијанску будућност која мистификује време: „месијанска” будућност коју опева Ујевић доноси разрешење за још увек делимично бесмислену и профану садашњост. У XVI песми циклуса Колајна, садашњост у јединству са субјектовом свешћу о обећаној трансценденцији разоткрива прошлост као „Ријеч Богоскрвну” (Исто: 72); назирањем месијанске будућности, субјект у својој садашњости доживљава радикално укидање дотадашњег облика времена. Субјектова интимизирана садашњост пружа увид у есхатолошки неизвесну природу догађаја о којој пише Дерида у есеју „Деконструкција актуелности”: институционално наметнута „етичка и политичка ургентност садашњости" (Дерида 2002: 93) уступа место феноменолошкој ургентности према којој субјект усмерава своју наду у жуђени догађај који би требало да се деси (l'arrivant), премда је тај догађај управо и дефинисан неизвесношћу свог доласка (в. Исто: 96). У XLVI песми Колајне, жуђена реализација будућности открива се као императив: иронијска вера у смисао садашњих патњи 
- иако време одлагањем поништава сваки смисао - обједињује садашњост и месијанску будућност чиме је егзистенцијалној беди садашњости супротстављен иманентни смисао времена. „(Ј)ер дивни мелем, који ране врачи / тече са ових руку милосрђа; / па ако душман човјечанство смрачи, / остани ведар: Дух је твоја Тврђа” (Ујевић 2003: 105). Уместо институционализације хаотичне прошлости које практикује колектив у Тестаменту, за Ујевића време свој смисао има у космичком логосу који ће се тек открити; слутња метафизике могућа је путем садашњости чији су емпиријски оквири независни од колектива и институција̄.

\section{IV. Закључак: Стевановићев сакрални бесмисао и Ујевићев небивствени смисао}

Време у Ујевићевом опусу је, дакле, под контролом субјекта тиме што је сведено на садашњост у којој се све одвија, при чему је одвијање циклично у трагично екстатичном уместо, као код Стевановића, хаотичном контексту. Мада присутна код обојице аутора, вечност иницира опречне односе код Стевановићевог субјекта силом приклоњеног каљанским законима, и Ујевићевог који, располажући деридијанским „одлучивањем”, спремно реструктурира вечност признавањем логоса који се дешава у свим сегментима времена. Док Стевановићев опис времена централну позицију даје прошлости (и употреби прошлих времена) у оквиру које су поистовећени судбина и институција, презенту наклоњени Ујевић сматра садашњост модусом искупљења времена у одсуству смисла који „институционално” време потире. Догађаји се за Ујевића нису, као за Стевановића, заувек већ одвили и тиме значењски укинули садашњост и будућност: они морају да се још једном одвију, и да понављањем приближе субјекту стварност у којој више нема бесмислених и зато неподношљивих патњи као у Свакидашњој јадиковичи. „Потребна дистанца и илузија" Стевановићеве прошлости, пак, ригидним озакоњавањем стварности утврђују субјектов идентитет: митски предодређена позиција у колективу јесте залог оног што субјект јесте. Садашњост, присутна у Tестаменту као пука контемплација те прошлости-мита, не укључује друштвене кодексе села Као, нити претендује да ревидира исконске апорије које Каљани ауторизују. Ујевић, који се слаже са Стевановићем у погледу садашњости као простора критике времена, инсистира на томе да се критика актуелизује укидањем не само историје већ и засебног идентитета, који је метафора вечитости неподношљивих патњи. Кроз онтолошку ревизију осим садашњости пролази и субјект, чији је идентитет једно са колективом, не у контексту колективних закона него искуства наде - универзалне жудње за тим да се „месијанска” будућност догоди или бар препозна. 


\section{ЛИТЕРАТУРА}

Барт 1975: R. Barthes, The Pleasure of the Text, New York: Hill and Wang Бењамин 2007: W. Benjamin, Illuminations, New York: Schocken Books Дерида 2002: J. Derrida, The Deconstruction of Actuality, in: E. Rottenberg (ed.), Negotiations: Interventions and Interviews, 1971-2001, Stanford: Stanford University Press, $85-116$.

Kејн 2007: P. J. Kain, Nietzsche, Eternal Recurrence, and the Horror of Existence, in: The Journal of Nietzsche Studies, 33 (2007), 49-63, https://core.ac.uk/ download/pdf/72853831.pdf, приступљено 28. 08. 2020.

Стевановић 2008: В. Стевановић, Тестамент, Крагујевац: Кораци.

Требежник 2019: L. Trebežnik, Being on the Brink of the Future - Jacques Derrida and Poetics of Waiting, in: Bogoslovni vestnik/Theological Quarterly 79 (2019) 2, стр. 347-356, https://www.teof.uni-lj.si/uploads/File/BV/ BV2019/02/Trebeznik.pdf, приступљено 28. 08. 2020.

Ујевић 2003: Т. Ујевић, Свакидашъа јадиковка, Подгорица: Граматик.

Nikola M. Đuran

\section{TIME IN THE NOVEL THE WILL BY VIDOSAV STEVANOVIĆ AND POETRY OF AUGUSTIN „TIN” UJEVIĆ}

Summary

The paper deals with the interdisciplinary analysis of time as a metaphysically independent phenomenon resisting the subject's need to accommodate it to his/her empirical quandaries. Regardless of the fears, desires or premonitions which the subject may harbor, time is determined by its immanent ontological objectives whose occurrence is often too strenuous for the subject to experience. Whereas in the novel by Stevanović time is addressed as inexplicable yet culturally quintessential category, Ujević views time as autonomous from the subject's mores and habitual experience, and thus prone to his/her personalized discourse. Stevanović accentuates the past as the emblem of time's monistic immutability, while according to Ujević time is a metaphysical expansion of the present, in which all elements appear equated by virtue of their belonging to the cycle of history. 